\title{
Czy trzeba zmniejszać stężenie cholesterolu u osób starszych?
}

\author{
Is it a need to reduce cholesterol in the elderly?
}

\author{
Barbara Cybulska ${ }^{1}$, Longina Kłosiewicz-Latoszek ${ }^{1,2}$ \\ ${ }^{1}$ Instytut Żywności i Żywienia w Warszawie \\ ${ }^{2}$ Zakład Medycyny Zapobiegawczej i Higieny Warszawskiego Uniwersytetu Medycznego
}

\section{Streszczenie}

U osób starszych związek między stężeniem cholesterolu całkowitego (TC) a ryzykiem epizodów sercowo-naczyniowych i zgonami jest słabszy niż u młodszych. Może to wynikać z wcześniejszego zgonu osób, u których stężenia TC są wyższe, jak również z chorób współistniejących, które są u nich powodem niższego stężenia tego lipidu.

Starsze osoby na ogół są rzadko włączane do badań klinicznych z zastosowaniem statyn, co ogranicza wyciągnięcie ostatecznych wniosków. Odnosi się to do prewencji pierwotnej. Zatem u osób po 75. roku życia bez rozpoznanej choroby układu sercowo-naczyniowego nie zaleca się terapii statynowej a priori z powodu niedostatecznych dowodów skutecznej prewencji. Decyzję powinni podjąć wspólnie lekarz i pacjent. Istnieje natomiast ogólny konsensus dotyczący stosowania statyn w starszym wieku w prewencji wtórnej, poparty korzystnymi dowodami z badań klinicznych.

Słowa kluczowe: osoby starsze, cholesterol, epidemiologia, statyny, wytyczne

Folia Cardiologica 2016; 11, 3: 202-208

\section{Wstęp}

Tytułowy problem jest poważny i kontrowersyjny z wielu powodów. Po pierwsze, ważne jest pytanie, jak zdefiniować starszy wiek. W różnych pracach istnieją różnice pod tym względem. Jedni badacze uznają, że jest to 70 lat i więcej, inni, że 75 lat i więcej, jeszcze inni - 80 lat i więcej. Ponadto, o ile u osób w wieku średnim do wcześnie starszego znana jest zależność pomiędzy stężeniem cholesterolu a ryzykiem choroby niedokrwiennej serca (IHD, ischemic heart disease), to u osób po 65. roku życia ulega ona osłabieniu, może jej nie być, a nawet staje się odwrotna. Strandberg i wsp. [1] nazwali ten fakt paradoksem cholesterolu w starszym wieku. Trzeba dodać, że chociaż proporcjonalne różnice w ryzyku zmniejszają się wraz z wiekiem, to całkowity wpływ stężenia cholesterolu (TC, total cholesterol) na roczną umieralność z powodu IHD jest dużo większy u osób starszych niż u młodszych. Absolutna różnica w rocznym ryzyku zgonów na IHD na 1 mmol różnicy TC była około 10-krotnie większa u osób w wieku 80-89 lat niż 40-49 lat [2].

Poważny problem stanowi właściwie brak randomizowanych badań klinicznych z zastosowaniem statyn u osób starszych. Jedyną próbą kliniczną wykonaną u osób w wieku 70-82 lata jest PROSPER [3], nie ma natomiast żadnego badania rozpoczętego wśród osób po 80. roku życia. Pewnej wiedzy na temat wpływu terapii statynowej na ryzyko u osób starszych dostarczają wyniki w podgrupach wiekowych, które ze względu na małą liczebność są przedstawiane w metaanalizach [4-8]. Jeszcze inną poważną sprawą, którą należy brać pod uwage przed rozpoczęciem terapii statyną, jest obecność chorób współistniejących i przyjmowanie wielu leków, z których niektóre mogą wejść w interakcję ze statyną, czemu sprzyja upośledzona funkcja nerek. Celem niniejszej pracy jest przedstawienie aktualnego stanu wiedzy na ten temat. 


\section{Badania obserwacyjne}

Stężenie cholesterolu

u osób w starszym wieku

Z badań obserwacyjnych, kiedy jeszcze nie było terapii statynowej lub była mniej rozpowszechniona, wynika, że stężenie cholesterolu zmniejsza się wraz z wiekiem. Przykładem może być Rancho Bernardo Study [9] i Honolulu Heart Program [10]. W Rancho Bernardo Study uczestniczyły 2344 osoby w wieku 50-93 lata (część przekrojowa) i 917 osób (część obserwacyjna). U mężczyzn w części przekrojowej wykazano zmniejszające się stężenia TC i cholesterolu frakcji lipoprotein o niskiej gęstości (LDL-C, low-density lipoprotein cholesterol) wraz z wiekiem badanych $(p<0,001)$. W 8-letniej obserwacji prospektywnej stężenia TC i LDL-C zmniejszały się u mężczyzn i u kobiet o około $1 \%$ na rok we wszystkich grupach wiekowych (50-64 lata, 65-74 lata $i \geq 75$ lat). Honolulu Heart Program rozpoczął się z udziałem 8006 mężczyzn urodzonych w latach 1900-1919. W czasie przystąpienia do niego (1965-1968 lata) mieli oni 45-68 lat. Zaplanowano 6-krotne badanie stanu zdrowia, w tym stężenia cholesterolu. W czwartym badaniu dokonanym między 1991 a 1993 rokiem uczestniczyło 3741 mężczyzn w wieku $71-93$ lata (80\% tych, którzy przeżyli). Badacze ocenili zmiany stężenia cholesterolu w ciągu ponad 20 poprzednich lat, tj. między trzecim (1971-1974) i czwartym badaniem (1991-1993), oraz porównali je z umieralnością. Wraz ze wzrastającym wiekiem uczestników średnie stężenie cholesterolu zmniejszało się znamiennie z 5,00 mmol/l u osób w wieku 71-74 lata do $4,93 \mathrm{mmol} / \mathrm{I}$ w wieku $75-79$ lat, $4,85 \mathrm{mmol} / \mathrm{I}$ w wieku 80 -84 lata i 4,61 mmol/l $\geq 85$ lat (test dla trendu p $<0,0001$ ).

Przyczyną odwrotnej zależności pomiędzy wiekiem i stężeniem cholesterolu może być z jednej strony to, że osoby z dużymi jego wartościami zmarły wcześniej z powodu choroby układu sercowo-naczyniowego, oraz z drugiej strony zły stan zdrowia osób starszych, który może kojarzyć się ze zmniejszeniem jego stężenia. Na ten drugi powód mogą wskazywać wyniki badania przekrojowego 2486 pacjentów w wieku ponad 65 lat [11]. W pracy tej jako kryterium złego stanu zdrowia przyjęto obecność innych chorób (Charlson index), małe stężenie albuminy oraz żelaza. Wykazano znamienną odwrotną korelację pomiędzy wiekiem i stężeniem cholesterolu $(-0,97 \mathrm{mg} / \mathrm{dl} / \mathrm{rok} ; \mathrm{p}<0,001)$. Okazało się $\mathrm{w}$ wieloczynnikowej analizie, że te wskaźniki złego stanu zdrowia odpowiadały w prawie 2/3 za wpływ wieku na stężenie cholesterolu. Po standaryzacji wyniku na ich obecność nie było związku między wiekiem a stężeniem TC. Autorzy sugerują, że niskie stężenie tego lipidu może być markerem złego stanu zdrowia. W innej obserwacji (724 uczestników, mediana wieku 89 lat) wykazano, że stężenia TC i LDL-C są małe u pacjentów z ciężkimi ostrymi i przewlekłymi chorobami (np. infekcje, nowotwory), a zgony z powodu tych chorób u osób z największymi stężeniami są znamiennie rzadsze
(10 lat obserwacji) [12]. Ponadto oszacowano, że większe o każdy $1 \mathrm{mmol} / \mathrm{l}$ stężenie TC wiązało się z mniejszym o 15\% ryzykiem zgonu (ryzyko względne [RR, relative risk]: 0,85; 95-proc. przedział ufności [Cl, confidence interval]: 0,79-0,91). U osób po 85. roku życia duże stężenie TC ( $\geq 6,5 \mathrm{mmol} / \mathrm{l})$ łączyło się z długowiecznością na skutek mniejszej umieralności z powodu infekcji i nowotworów.

\section{Cholesterol a zgony ogółem}

W większości badań obserwacyjnych u osób starszych dominuje negatywny związek pomiędzy stężeniem TC i zgonami ogółem. Małe stężenie TC kojarzy się z największą umieralnością. W celu zilustrowania tego faktu warto przytoczyć wyniki dwóch badań, tj. wspomnianego już wyżej Honolulu Heart Program [10] i Turku Elderly Study [13].

Jak poprzednio wspomniano, w populacji Honolulu Heart Program średnie stężenie cholesterolu zmniejszało się znamienne w związku ze wzrostem wieku uczestników. Co zaś tyczy się zgonów, to ich RR wynosiło 0,72 (95\% Cl: 0,60-0,87); 0,60 (95\% Cl: 0,49-0,74) i 0,65 (95\% Cl: 0,53-0,80), odpowiednio w drugim, trzecim i czwartym (najwyższym) kwartylu stężeń TC, w porównaniu z pierwszym kwartylem. Tylko u osób z niskim stężeniem cholesterolu w obu oznaczeniach (przed i po 20 latach) było znamiennie więcej zgonów ogółem (RR: 1,64; 95\% Cl: 1,13-2,36). Autorzy napisali, że nie potrafili wyjaśnić swoich wyników. Można jednak spekulować na temat ewentualnej obecności innych chorób przewlekłych, które były związane z małym stężeniem cholesterolu i zwiększonym występowaniem zgonów.

Wyniki 12-letniej obserwacji 1032 osób w wieku 70 i więcej lat (Turku Elderly Study) potwierdziły, że niskie stężenia TC są związane z większym ryzykiem zgonów ogółem [13]. Jednak z drugiej strony również duże stężenie TC kojarzyło się z podobnie dużą umieralnością. Ponadto znamiennie mniej zgonów z powodu chorób układu sercowo-naczyniowego było u osób, u których stężenie cholesterolu mieściło się w najniższym kwartylu. W tym badaniu związek pomiędzy TC i zgonami miał kształt litery U.

Ostatnio opublikowano prace, która rzuca więcej światła na związek stężenia cholesterolu LDL z umieralnością [14]. Autorzy, przystępując do badania, wyszli z założenia, że w starszym wieku, na skutek różnych chorób, stężenie LDL-C może nie odzwierciedlać stężeń w ciągu życia i ryzyko może być niedoszacowane. Aby przezwyciężyć potencjalny wpływ niedoszacowania stężenia tego lipidu na ryzyko zgonu na skutek jego niższego stężenia u osób starszych, podjęto badania genetyczne. Badacze utworzyli genetyczny wskaźnik ryzyka (GRS, genetic risk score) na podstawie 51 polimorfizmów pojedynczego nukleotydu (SNP, single nucleotide polymorphism) związanych ze stężeniami LDL-C. W badaniu uczestniczyły 3 holenderskie kohorty liczące 7635 uczestników. Do LLS (Leiden Longevity Study) włączono rodziny, w których żyły przynajmniej 2 osoby z rodzeństwa i spełniały 
kryteria wiekowe 89 lat lub więcej dla mężczyzn i 91 lat lub więcej dla kobiet. W Leiden 85 Plus były osoby, które ukończyły 85 lat pomiędzy 1 września 1997 i 1 września 1999 roku, z kolei do Rotterdam Study zaproszono osoby w wieku 55 lat i więcej.

Aż do 90. roku życia w każdej grupie wiekowej osoby z wysokim LDL GRS miały wyższe stężenia LDL-C $\left(p=0,010\right.$ do $\left.p=1,1 \times 10^{-16}\right)$. Częstość alleli związanych ze wzrostem stężenia tego lipidu zmniejszała się wraz z wiekiem. Co więcej, osoby z genetyczną predyspozycją do długowieczności miały znamiennie niższy LDL GRS w porównaniu z osobami dobranymi pod względem wieku z populacji generalnej.

Wysoki LDL GRS kojarzył się ze zwiększoną umieralnością w wieku $\geq 90$ lat, ze zwiększeniem ryzyka zgonu o 13\% (RR: 1,13; 95\% Cl: 1,00-1,26) w porównaniu z najniższym GRS.

Autorzy uznali, że wyniki ich badania wykazały, że genetyczna predyspozycja do dużych stężeń LDL-C przyczynia się do większej umieralności przez całe życie, łącznie z osobami najstarszymi, i że korzystny LDL GRS wiąże się z długowiecznością.

\section{Cholesterol a zgony sercowo-naczyniowe}

Badania epidemiologiczne niezmiennie wykazują, że ryzyko chorób układu sercowo-naczyniowego wzrasta z wiekiem u obu płci i że wiek jest jednym z najsilniejszych czynników prognozujących ryzyko. Jednak wpływ stężenia cholesterolu na zagrożenie tymi chorobami i zgon z ich powodu, a w szczególności na IHD, u osób starszych pozostaje przedmiotem debaty, gdyż wyniki badań są niejednoznaczne.

W badaniach kohortowych Kaiser Permanente Study [15] i Framingham Heart Study [16] znamienna była w szerokim zakresie wieku zależność pomiędzy stężeniem cholesterolu i zgonami wieńcowymi u osób bez choroby układu sercowo-naczyniowego w wywiadzie, jak i z tą chorobą, natomiast w kohorcie EPESE u osób po 70. roku życia nie było związku omiędzy stężeniami TC nawet 240 mg/dl i wyższym i obecnością choroby wieńcowej, zgonami z tego powodu i zgonami ogółem [17]. W analizie tej samej kohorty Corti i wsp. [18] dokonali standaryzacji wyników na wskaźnik złego stanu zdrowia (stężenia żelaza we krwi i albuminy w surowicy). Po tej standaryzacji zgony wieńcowe i zgony ogółem były znamiennie częstsze u starszych osób ze stężeniem TC większym lub równym 240 mg/dl.

Jednak szczególnie warte przedstawienia, ze względu na liczebność badanych (n 900000 osób), są wyniki metaanalizy pod nazwą Prospectives Studies Collaboration [2]. Okazało się, że siła zależności pomiędzy stężeniami cholesterolu i zgonami wieńcowymi słabła wraz z wiekiem, niemniej, co wymaga podkreślenia, pozostawała statystycznie znamienna. Do metaanalizy włączono 61 prospektywnych badań populacyjnych (głównie Europa Zachodnia i Ameryka Północna) z udziałem osób w wieku 40-89 lat bez choroby naczyniowej. Czas obserwacji wynosił 13 lat. W tym czasie wystąpiło około 34000 zgonów wieńcowych, 12000 zgonów z powodu udaru mózgu i 10000 innych zgonów naczyniowych. Stwierdzono najsilniejszy związek stężenia cholesterolu z ryzykiem zgonu na chorobę wieńcową w najmłodszej grupie wiekowej, tj. 40-49 lat. U osób w tym wieku stężenie TC mniejsze o $1 \mathrm{mmol} / \mathrm{l}$ (39 mg/dl) było związane z mniejszym o 56\% ryzykiem zgonu wieńcowego (współczynnik ryzyka [HR, hazard ratio]: 0,44; 95\% Cl: 0,42-0,48). Biorąc pod uwage starsze grupy wiekowe, tj. 50-69 lat i 70-89 lat, HR wynosił odpowiednio 0,66 (95\% Cl: 0,65-0,68) i 0,83 (95\% Cl: 0,81-0,85). Jednakże w związku ze wzrostem absolutnego ryzyka epizodów w najstarszej grupie, całkowita liczba epizodów, którym można by zapobiec, jest większa u osób starszych niż młodszych. Należy dodać, że najsilniejszym czynnikiem prognostycznym dla zgonu wieńcowego we wszystkich grupach wiekowych był stosunek TC do cholesterolu frakcji lipoprotein o dużej gęstości (HDL-C, high-density lipoprotein cholesterol) (w 40\% bardziej informacyjny niż cholesterol nie-HDL i ponad 2-krotnie bardziej niż TC).

\section{Badania kliniczne}

Wobec wydłużania się życia i dużego ryzyka związanego z wiekiem powstaje pytanie, czy u osóbw starszym wieku stosować statyny? Szczególnie dotyczy to osób powyżej 80. roku życia, gdyż w zasadzie brak jest randomizowanych badań klinicznych z uczestnikami w tym wieku. Jedyną próbą kliniczną przeprowadzoną u osób starszych, jak już wspomniano, jest PROSPER [3]. Uczestniczyły w niej 5804 osoby w wieku 70-82 lata, jednak mało z nich przekroczyło 80 lat. Jakąkolwiek chorobę sercowo-naczyniową miało 45,2\% osób w grupie prawastatyny i 43,2\% w grupie placebo. Leczenie prawastatyną zmniejszyło stężenie LDL-C o 34\%. Średnio po 3,2 roku występowanie głównych epizodów sercowo-naczyniowych u wszystkich osób stosujących prawastatynę zmniejszyło się o 15\% (HR: 0,85; 95\% Cl: 0,74-0,97), a zgonów wieńcowych razem z zawałem serca bez zgonu o 19\% (HR: 0,81; 95\% Cl: 0,69-0,94). Nie było zmiany ryzyka udaru mózgu, chociaż zmniejszyło się występowanie przemijającego niedokrwienia mózgu (HR: 0,75; 95\% Cl: 0,55-1,00). Nie było redukcji zgonów ogółem (HR: 0,97; 95\% Cl: 0,83-1,14). U uczestników z prewencji pierwotnej ryzyko głównych epizodów sercowo-naczyniowych nie uległo znamiennej zmianie (HR: 0,94; 95\% Cl: 0,77-1,15). Z kolei w badaniu prewencji pierwotnej JUPITER z rosuwastatyna, kontrolowanym placebo, w którym wśród 18702 zdrowych uczestników było 5695 osób powyżej 70. roku życia, po dwóch latach (mediana) obserwowano znamienne zmniejszenie występowania głównych epizodów sercowo-naczyniowych (HR: 0,61; 95\% Cl: 0,46-0,82), natomiast redukcja zgonów ogółem była nieznamienna (HR: 0,80; 95\% Cl: 0,80-1,04) [19]. W badaniu HPS (pacjenci z IHD, innymi chorobami układu 
sercowo-naczyniowego lub cukrzycą) wśród 20536 chorych w wieku 40-80 lat randomizowanych do przyjmowania simwastatyny lub placebo było 5806 osób (28\%) w wieku 70-80 lat [20]. Wyniki oceniono w zależności od grupy wiekowej: poniżej $65,65-69$ i $\geq 70$ lat. We wszystkich grupach wiekowych obserwowano znamienną redukcję epizodów sercowo-naczyniowych, odpowiednio o 24\%, 23\% i $18 \%$ w ciągu 5 lat leczenia simwastatyną.

Wyniki tych badań zostały przedstawione w niniejszej pracy ze względu na dużą liczbę osób starszych wśród uczestników. Jednak, jak widać, za wyjątkiem niewielu pacjentów w PROSPER, nie ma w nich uczestników w wie$k u \geq 80$ lat. Poza tym rezultaty $w$ prewencji pierwotnej ( $\geq 70$ lat) są sprzeczne, na przykład korzyść kliniczna (redukcja liczby chorób układu sercowo-naczyniowego) z terapii rosuwastatyną w JUPITER i brak korzyści z terapii prawastatyną w PROSPER. Być może wynika to z różnicy efektu hipolipemizującego obu statyn.

Efekty kliniczne terapii statynowej u osób starszych zostały podsumowane w metaanalizach obejmujących badania prewencji wtórnej $[4,5]$ i pierwotnej $[6,7]$. Afilalo i wsp. objęli metaanalizą 9 prób klinicznych prewencji wtórnej ze statynami versus placebo, w których uczestniczyło 19569 pacjentów w wieku 65-82 lata [4]. Średnia ważona obserwacji wynosiła 4,9 roku. Wyniki okazały się korzystne, gdyż na podstawie szacunków w okresie ponad 5 lat względna redukcja zgonów ogółem wynosiła 22\% (RR: 0,78; 95\% Cl: 0,65-0,89), zgonów wieńcowych 30\% (RR: 0,70; 95\% Cl: 0,53-0,83), zawałów serca bez zgonu 26\% (RR: 0,74; 95\% Cl: 0,56-0,94), konieczności rewaskularyzacji 30\% (RR: 0,70; 95\% Cl: 0,53-0,83) i udarów mózgu 25\% (RR: 0,75; 95\% Cl: 0,56-0,94). Liczba pacjentów, którzy powinni być leczeni w tym czasie, aby uniknąć jednego zgonu (NNT, number needed to treat), wynosiła 28 (95\% Cl: 15-56).

W ostatnio opublikowanej 3-letniej obserwacji 24367 pacjentów ( $\geq 65$. rż.) z chorobą wieńcową, którym przy wypisaniu ze szpitala (lata 2005-2009) przepisano statynę, okazało się, że przyjmowanie statyn łączyło się ze znamiennie mniejszym ryzykiem zgonów ogółem (HR: 0,89; 95\% Cl: 0,84-0,93) i głównych epizodów wieńcowych (HR: 0,92; 95\% Cl: 0,88-0,96) [21]. Intensywna terapia natomiast, w porównaniu z mało intensywną lub umiarkowaną, nie miała wpływu na mniejsze ryzyko zgonów ogółem i występowanie głównych epizodów wieńcowych.

Niedawno włączono do metaanalizy pięć badań klinicznych z intensywną terapią statynową (prewencja wtórna) u osób starszych, tj. w wieku 65 lat oraz starszych roku życia ( $n=5626)$, i porównano wyniki z tymi stosującymi terapię mniej intensywną (4 próby kliniczne) lub placebo (1 próba kliniczna), łącznie 5506 pacjentów [5]. Intensywna terapia statyną nie miała przewagi nad terapią umiarkowaną lub kontrolowaną placebo, w odniesieniu do zgonów ogółem (RR: 0,97; 95\% Cl: 0,87-1,09) i zgonów sercowych (RR: 0,95; 95\% Cl: 0,80-1,13), pomimo redukcji LDL-C średnio o 55,4\%. Obserwowano natomiast znamienną korzystną różnice w występowaniu zawału serca (RR: 0,78; 95\% Cl: 0,65-0,94), udarów mózgu (RR: 0,72; 95\% Cl: 0,56-0,94) i potrzeby rewaskularyzacji (RR: 0,69; 95\% Cl: 0,52-0,90). Według autorów pracy ich wyniki wspierają stosowanie intensywnej terapii statynowej u pacjentów $\geq 65$. roku życia z chorobą wieńcową.

Kilka lat temu ukazała się metaanaliza randomizowanych kontrolowanych prób klinicznych leczenia statynami osób bez rozpoznanej choroby układu sercowo-naczyniowego, ale obciążonych czynnikami ryzyka [6]. Porównano w niej wyniki u osób po 65. roku życia ( $n=21$ 720) z tymi u osób młodszych ( $n=26$ 018). Średni okres obserwacji wynosił 4,1 roku. Zarówno u osób starszych, jak i u młodszych nie było znamiennej różnicy zgonów ogółem względem grup kontrolnych (placebo), iloraz szans (OR, odds ratio) odpowiednio 0,95 (95\% Cl: 0,80-1,12) i 0,89 (95\% Cl: 0,74-1,04). W grupie wiekowej powyżej 65 lat nie stwierdzono znamienności różnicy wystąpienia głównych epizodów wieńcowych - OR: 0,86 (95\% Cl: 0,67-1,09), natomiast u osób do 65. roku życia różnica była znamienna - OR: 0,62 (95\% Cl: 0,42-0,87). U starszych osób leczenie statyną nie zmniejszyło też znamiennie epizodów naczyniowo-mózgowych, podczas gdy znamienna korzyść była obserwowana u młodszych. W obu grupach nie wystąpiło więcej nowotworów w związku z terapią statynową.

Ostatnio opublikowano metaanalizę 8 prób klinicznych prewencji pierwotnej w których uczestniczyły 24674 osoby w wieku $\geq 65$ lat (średnia $73 \pm 2,9$ roku) z czasem obserwacji 3,5 $\pm 1,5$ roku [7]. U leczonych statynami średnia redukcja LDL-C wyniosła 31\% (spadek o 1,16 \pm 0,26 mmol/I z 3,76 $\pm 0,73 \mathrm{mmol} / \mathrm{l})$, a u przyjmujących placebo o $6 \%$

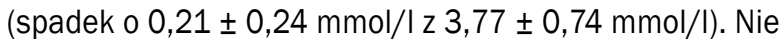
obserwowano redukcji zgonów ogółem pod wpływem statyn (ryzyko względne [RR, relative risk] 0,941; 95\% Cl: 0,856-1,035) i zgonów sercowo-naczyniowych (RR: 0,907; 95\% Cl: 0,686-1,199). Było natomiast znamiennie mniej zawałów serca o 39,4\% (RR: 0,606; 95\% Cl: 0,434-0,847) i udarów mózgu o 23,8\% (RR: 0,762; 95\% Cl: 0,626-0,926). Z metaanalizy wynika, że u starszych pacjentów bez choroby serowo-naczyniowej statyny zmniejszyły występowanie zawałów serca i udarów mózgu, ale nie przedłużyły życia w tej krótkiej obserwacji.

Szeroko znaną metaanalizą jest dokonana przez Cholesterol Treatment Trialists' Collaboration, do której włączono 26 randomizowanych badań klinicznych ze statynami (prewencja pierwotna i wtórna łącznie) [8]. Czas leczenia powinien był wynosić przynajmniej 2 lata. Autorzy ocenili między innymi w 21 badaniach (statyna v. kontrola) redukcję występowania głównych epizodów sercowo-naczyniowych, w zależności od zmniejszenia stężenia LDL-C o $1 \mathrm{mmol} / \mathrm{l}$, biorąc pod uwagę wiek uczestników. Względne obniżenie ryzyka wynosiło, odpowiednio do wieku, 16\% (RR: 0,84; 99\% Cl: 0,73-0,97) u osób powyżej 75 . roku życia, 22\% 
(RR: 0,78; 99\% Cl:0,74-0,83) u osób w wieku 65-75 lat i 22\% (RR: 0,78; 95\% Cl:0,75-0,82) u tych w wieku do 65 lat. Aby uniknąć jednego głównego epizodu sercowo-naczyniowego, należy leczyć odpowiednio 36, 29 i 37 osób [22]. Intensywna terapia statynowa versus mniej intensywna (5 badań) łączyła się ze znamiennym zmniejszeniem występowania głównych epizodów wieńcowych tylko u osób w wieku do 65 lat i 65-75 lat, nie było natomiast korzyści u tych poniżej 75. roku życia (RR: 0,78; 99\% Cl: 0,52-1,18).

\section{Co podano w wytycznych}

dotyczących postępowania

z cholesterolem u osób starszych

Eksperci European Society of Cardiology (ESC) i European Atherosclerosis Society (EAS) w wytycznych postępowania z lipidami zalecają stosowanie statyn u osób starszych z rozpoznaną chorobą układu sercowo-naczyniowego, w taki sam sposób jak u młodszych pacjentów [23]. Jest to I stopień rekomendacji z poziomem wiarygodności danych B. Jednakże ze względu na choroby współistniejące i zmienioną farmakokinetykę zwracają uwagę na rozpoczynanie leczenia od małej dawki statyny, a następnie ostrożne zwiększanie, aby osiągnąć ten sam cel terapeutyczny co u młodszych chorych (I C). Co się tyczy prewencji pierwotnej u osób starszych, to terapię statyną można rozważyć, szczególnie jeśli poza wiekiem występuje inny czynnik ryzyka (Ilb B). Z tego wynika, że jest to opcja terapeutyczna. Należy dodać, że nie ma informacji, kto to są osoby starsze.

W wytycznych American College of Cardiology (ACC) i American Heart Association (AHA) na temat postępowania z cholesterolem eksperci wyróżnili dwie grupy wiekowe, tj. osób w wieku 65-75 lat i powyżej 75. roku życia [24]. Ci pierwsi, jeśli mają chorobę układu sercowo-naczyniowego na tle miażdżycy, powinni być leczeni silną statyną, ci drudzy statyną o umiarkowanej intensywności. Wyróżniono także chorych na cukrzyce. Młodszym pacjentom z tą chorobą (65-75 lat) zaleca się statynę o umiarkowanej intensywności. Nie ma natomiast zalecenia dla pacjentów po 75. roku życia. Osoby starsze bez choroby układu sercowo-naczyniowego ze stężeniem LDL-C powyżej 190 mg/dl powinny przyjmować silną statynę bez względu na wiek. Ostatnią grupą są osoby starsze bez choroby układu sercowo-naczyniowego ze stężeniem LDL-C w granicach 70-189 mg/dl obciążone 10-letnim ryzykiem wystąpienia epizodu sercowo-naczyniowego przekraczającym 7,5\% (wg kalkulatora ryzyka dla populacji amerykańskiej). Jeśli są oni w wieku 65-75 lat, to zaleca się statynę o umiarkowanej intensywności do silnej. Nie ma rekomendacji dla osób, które ukończyły 75 lat. W wytycznych nie podano docelowych stężeń LDL-C.

Inna grupa ekspertów AHA przygotowała w tym samym roku stanowisko naukowe na temat wtórnej prewencji chorób układu sercowo-naczyniowego na tle miażdżycy u osób starszych [25]. Autorzy napisali: „Chociaż termin 'starsi' w tym dokumencie odnosi się do osób w wieku 65 lat i starszych, to nacisk (dostępne są dane) jest położony na osoby w wieku 75 lat i starsze, u których wyzwania związane z wiekiem są największe". Za wiarygodne uznali dowody wspierające terapię hipolipemizującą we wtórnej prewencji choroby wieńcowej do około 85. roku życia. Zwraca uwage, że u pacjentów z chorobą układu sercowo-naczyniowego na tle miażdżycy eksperci przedstawili docelowe stężenia LDL-C, w odróżnieniu od wcześniej wspomnianych wytycznych ACC/AHA na temat postępowania z cholesterolem [24]. Sa to wartości poniżej $100 \mathrm{mg} / \mathrm{dl}$ dla większości pacjentów obciążonych dużym ryzykiem (tak jak dla osób młodszych). U pacjentów cechujących się bardzo dużym ryzykiem można rozważyć LDL-C poniżej $70 \mathrm{mg} / \mathrm{dl}$ jako opcję, „jednak do tego celu należy zbliżać się ostrożnie, biorąc pod uwagę ryzyko działań niepożądanych związanych z większymi dawkami statyn". Dla pacjentów ze stężeniem triglicerydów większym lub równym 200 mg/dl zaproponowano stężenie cholesterolu nie-HDL poniżej 130 mg/dl. Najważniejszymi lekami hipolipemizującymi we wtórnej prewencji u osób starszych pozostają statyny, których stosowanie należy rozpoczynać od małych dawek, stopniowo je zwiększając, jeśli są tolerowane, tak aby osiągnąć obniżenie stężenia LDL-C o 30-40\%. Poza statynami „fundamentalne znaczenie w strategii prewencji nawracających epizodów sercowo-naczyniowych w każdym wieku mają zwiększenie aktywności fizycznej i dieta, pomimo ograniczonych dowodów u seniorów". Mimo przedstawionych powyżej zaleceń, w kwestii decyzji przepisania statyny starszym pacjentom autorzy wyrażają opinię, że wymaga ona oceny oczekiwanej długości życia, celów terapii, czasu do uzyskania korzyści z leczenia, chorób współistniejących i tego, co może powodować powikłania związane z leczeniem.

W artykule podsumowującym na rok 2016 zasady postępowania w dyslipidemii eksperci amerykańskiego National Lipid Association w decyzji dotyczącej rozpoczęcia terapii statyną u osób w wieku 75 lat i starszych (w prewencji pierwotnej) napisali, że należy przedyskutować z pacjentem ryzyko i korzyści, potencjalne interakcje lekowe oraz wziąć pod uwagę ogólny stan zdrowia, w aspekcie oczekiwanego dalszego życia i jego jakości, koszty leczenia oraz preferencje pacjenta [26].

Oczywiste jest, że w postępowaniu z lipidamii u osób starszych należy się kierować wytycznymi opracowanymi przez grupy ekspertów towarzystw naukowych. Jednak pewną pomocą mogą być niedawno przedstawione propozycje grupy ekspertów australijskich dla osób w wieku większym lub równym 65 lat [27]. Przed podjęciem decyzji o terapii hipolipemizującej radzą oni rozważenie obecności następujących czynników ryzyka: przebyta choroba układu sercowo-naczyniowego na tle miażdżycy, nadciśnienie tętnicze (> 150/80 mm Hg lub leczenie hipotensyjne), małe stężenie HDL, cukrzyca, przewlekła choroba nerek (GFR < $60 \mathrm{ml} / \mathrm{d}$.) zespół metaboliczny, hipertriglicerydemia (TG > 2,3 mmol/I 
[> $200 \mathrm{mg} / \mathrm{dl}]$ ) jednocześnie z dużym ryzykiem, wskaźnik uwapnienia tętnic wieńcowych powyżej 300 jednostek Agatstona, choroba tętnic obwodowych. Trzeba również wziąć pod uwage przewidywaną „odpowiednią” długość życia (rozsądne przyjąć $\geq 5$ lat) oraz przewidywaną przewage korzyści nad działaniami niepożądanymi. Statyny powinno się stosować w minimalnych skutecznych dawkach, aby zmniejszyć stężenie LDL-C przynajmniej o 30\% i/lub osiągnąć docelowy LDL-C, tj. poniżej 2,5 mmol/I (jeśli nie rozpoznano choroby układu sercowo-naczyniowego) i poniżej 1,8 mmol/l (jeśli występuje choroba układu sercowo-naczyniowego). Pacjenci stosujący statyny wymagają bardziej starannego monitorowania działań niepożądanych. Australijscy eksperci proponują dodanie ezetimibu do małej lub umiarkowanej dawki statyny albo monoterapię nim w przypadku nietolerancji statyn.

Do możliwych wyjątków niestosowania statyn zaliczono krótki czas przeżycia (< 5 lat), pacjentów bez rozpoznanych czynników ryzyka choroby układu sercowo-naczyniowego dodatkowo z niskim wskaźnikiem Agatstona (< 100 j.) i małym stężeniem LDL-C (<2,5 mmol/l) niespowodowanym wtórnymi przyczynami (duża utrata masy ciała, choroby przewodu pokarmowego lub nowotwory). Ponadto do przyczyn niestosowania statyny mogą należeć zwiększone ryzyko działań niepożądanych, niski wskaźnik masy ciała ([BMI, body mass index] $<18 \mathrm{~kg} / \mathrm{m}^{2}$ ), ciężkie choroby współistniejące i wiek powyżej 80 lat.

\section{Podsumowanie}

W badaniach obserwacyjnych u osób starszych (> 65. rż.) wykazano słabszy związek stężenia TC z ryzykiem sercowo-naczyniowym oraz zgonami w porównaniu z sytuacją wśród osób młodszych. Jednak osoby starsze cechuje wyższe absolutne ryzyko ze względu na wiek. Wśród przyczyn tej słabszej zależności wymienia się wcześniejszy zgon z powodu choroby układu sercowo-naczyniowego u osób z większym stężeniem cholesterolu, częstsze występowanie innych chorób przewlekłych, niedożywienie i spadek masy ciała [26]. Wszystko to może być powodem niższych stężeń cholesterolu. Poza tym większą rolę w zwiększeniu zagrożenia epizodem mogą odgrywać nielipidowe czynniki ryzyka, poprzez wpływ na niestabilność blaszki miażdżycowej, jej pęknięcie i/lub zakrzepice [26].

Obecnie dostępne dane o tym, czy statyny przyczyniają się do redukcji liczby zachorowań i zgonów z powodu choroby układu sercowo-naczyniowego u osób w starszym wieku, nie są jednoznaczne, szczególnie w odniesieniu do prewencji pierwotnej. Starsze osoby ogólnie nie są włączane do badań klinicznych, a jeśli tak, to dotyczy to osób w lepszej kondycji i zdrowszych niż ci żyjący w społeczeństwie. Być może, odpowiedź na powyższe pytanie przyniosą wyniki rozpoczętego badania STEERS z udziałem 10000 osób powyżej 70. roku życia [28]. Badacze ocenią wpływ leczenia statyną na długość życia, prewencję zawału serca, demencję i niesprawność.

Istnieje ogólny konsensus w przedstawionych wytycznych, aby zastosować terapię statyną u osób w starszym wieku z kliniczną chorobą układu sercowo-naczyniowego, gdyż dowody z prób klinicznych wspierają takie postępowanie. W odniesieniu do prewencji pierwotnej po 75 . roku życia dowód jest ograniczony i powinien być przedmiotem klinicznej oceny pacjenta i jego akceptacji dla terapii po przedstawieniu ewentualnych korzyści i działań niepożądanych. U osób starszych często występuje kilka chorób i przyjmują wiele leków, tak więc może być trudno przewidzieć u nich skutki leczenia oraz ocenić korzyści i szkodliwość. W tej sytuacji wspólna decyzja należy do lekarza i pacjenta. Jak wcześniej napisano, eksperci europejscy proponują rozważenie u osób starszych leczenia statyną, jeśli poza wiekiem istnieje dodatkowy czynnik ryzyka (nie jest to silna zalecenie - IIb B) [23], a eksperci amerykańscy w ogóle nie uwzględnili tej grupy wiekowej w swoich wytycznych [24]. Pomoca przy podjęciu decyzji u konkretnego pacjenta mogą być przedstawione propozycje australijskie [27].

\section{Konflikt interesów}

Autorki deklarują brak konfliktu interesów.

\section{Abstract}

The relationship between serum total cholesterol (TC) and the risk of cardiovascular events and mortality is weaker in the elderly people than in the younger ones. It can result from earlier mortality those with high TC and as well as comorbidities associated with lower levels of this lipid.

The older people are generally rarely included in the clinical trials with statins. This limits firm conclusions. Thus in the people $75+$ years without established cardiovascular disease statin treatment is not recommended a priori, because of insufficient evidence of preventive effect. The decision should be taken by physician and patient together. However there is a general consensus to use statins in the elderly in secondary prevention, supported by benefits in clinical trials.

Key words: the elderly, cholesterol, epidemiology, statins, guidelines

Folia Cardiologica 2016; 11, 3: 202-208 


\section{Piśmiennictwo}

1. Strandberg T., Kolehmainen L., Vuorio A. Evoluation and treatment of older patients with hypercholesterolemia. A clinical review. JAMA 2014; 312: 1136-1144.

2. Lewington S., Whitlock G., Clarke R. i wsp. Prospective Studies Collaboration. Blood cholesterol and vascular mortality by age, sex and blood pressure: a meta-analysis of individual data from 61 prospective studies with 55000 vascular deaths. Lancet 2007; 370: 1829-1839.

3. Shepherd J., Blauw G.J., Steele R. i wsp. Pravastatin in elderly individuals at risk of cardiovascular disease (PROSPER): a randomized controlled trial. Lancet 2002; 360: 1623-1630.

4. Afilalo J., Duque G., Steele R. i wsp. Statins for secondary prevention in elderly patients: a hierarchical Baysian meta-analysis. J. Am. Coll. Cardiol. 2008; 51: 37-47.

5. Yan Y.L., Qui B., Hu L.J. i wsp. Efficacy and safety evaluation of intensive statin therapy in older patients with coronary heart disease a systematic review and meta-analysis. Eur. J. Clin. Pharmacol. 2013; 69: 2001-2009.

6. Brugts J.J., Yetgin T., Hoeks S. i wsp. The benefits of statins in people without established cardiovascular disease but with cardiovascular risk factors: met-analysis of randomized controlled trials. Br. Med. J. 2009; 338: b2376.

7. Savarese G., Gotto A., Paolillo S. i wsp. Benefits of statins in elderly subjects without established cardiovascular disease. A meta-analysis. J. Am. Coll. Cardiol. 2013; 62: 2090-2099.

8. Baigent C., Blacwell L., Emberson J. i wsp. Efficacy and safety more intensive lowering of LDL cholesterol: a meta-analysis of data from 170000 participants in 26 randomized trials. Cholesterol Treatment Trialists' Collaboration. Lancet 2011; 276: 1670-1681.

9. Ferrara A., Berrett-Connor E., Shan J. Total, LDL and HDL cholesterol decrease with age in older men and women. Rancho Bernardo Study 1984-1994. Circulation 1997; 96: 37-43.

10. Schatz I., Masaki K., Yano K. i wsp. Cholesterol and all-cause mortality in elderly people from the Honolulu Heart Program: a cohort study. Lancet 2001; 358: 351-355.

11. Volpato S., Zuliani G., Guralnik J.M. i wsp. The inverse association between age and cholesterol level among older patients. The role of poor health status. Gerontology 2001; 47: 36-45.

12. Weverling-Rijnsburger A.W., Blauw G.J., Lagaay A.M. i wsp. Total cholesterol and risk of mortality in the oldest old. Lancet 1997; 350: 1119-1123.

13. Upmeier E., Lavonius S., Lehtonen A. i wsp. Serum lipids and their association with mortality in the elderly: a prospective cohort study. Aging Clin. Exp. Res. 2009; 21: 424-430.

14. Postmus I., Deelen J., Sadaghat S. i wsp. LDL cholesterol still a problem of old age? A Mendelian randomization study. Int. J. Epidemiol. 2015; 44: 604-612.

15. Rubin S.M., Sidney S., Black D.M. i wsp. High blood cholesterol in elderly men and the excess of coronary heart disease. Ann. Intern. Med. 1990; 113: 916-920.
16. Wong N.D., Wilson P.W., Kannel W.B. Serum cholesterol as a prognostic factor after myocardial infarction. The Framingham Heart Study. Ann. Intern. Med. 1991; 115: 687-693.

17. Krumholz H.M., Seeman T.E., Mervill S.S. i wsp. Lack of association between cholesterol and coronary heart mortality and morbidity and all-cause mortality in persons older than 70 years. JAMA 1994; 272 : 1334-1340.

18. Corti M.C., Guralnik J.M., Salive M.E. i wsp. Clarifying the direct relation between total cholesterol level and death from coronary heart disease in older patients. Ann. Intern. Med. 1997; 126: 753-760.

19. Glynn R.J., Koenig W., Nordesgaard B.G. i wsp. Rosuwastatin for primary prevention in older persons with elevated C-reactive protein and low to average low-density lipoprotein cholesterol levels: exploratory analysis of a randomized trial. Ann. Intern. Med. 2010; 152: 488-496.

20. Heart Protection Study Collaborative Group MRC/BHF Heart Protection Study of cholesterol lowering with simvastatin in 20536 high risk individuals: a randomized placebo-controlled trial. Lancet 2002; 360: 7-22.

21. O'Brien E.C., Wu J., Schulte P.J. i wsp. Statin use, intensity and 3-year clinical outcomes among older patients with coronary artery disease. Am. Heart J. 2016; 173: 27-34.

22. Fulcher J., O'Connell R., Simes J. i wsp. Effects of statin therapy by age in a meta-analysis of individual patient data from 174000 patients in the Cholesterol Treatment Trialists' Collaboration Study. Poster presented a American Heart Association 2013. Scientific Sessions and Resuscitation Science Symposium. 16-20 listopada, 2013, Dallas, Texas.

23. Reiner Ž., Catapano A.L., De Backer G. i wsp. ESC/EAG Guidelines for the management of dyslipidaemias. The Task Force for the management of dyslipidaemias of the European Society of Cardiology (ESC) and the European Atherosclerosis Society. Eur. Heart J. 2011; 32: 1769-1818.

24. Stone N.J., Robinson J.G., Lichtenstein A.H.; American College of Cardiology/American Heart Association Task Force on Practice Guidelines. 2013 ACC/AHA guideline on the treatment of blood cholesterol to reduce atherosclerotic cardiovascular risk in adults: a report of the American College of Cardiology/American Heart Association Task Force on Practice Guidelines. J. Am. Coll. Cardiol. 2014; 63: 2889-2934.

25. Fleg J., Forman D.E., Berra K. i wsp. Secondary prevention of atherosclerotic cardiovascular disease in older adults: a scientific statement from American Heart Association. Circulation 2013; 128: 2422-2446.

26. Bays H.E., Jones P.H., Orringer C.E. i wsp. National Lipid Association Annual Summary of Clinical Lipidology 2016. J. Clin. Lipidol. 2016; 10: S1-S43.

27. Craig I.H., Colquhoun D., Kostner K. i wsp. Lipid-modifying therapy in elderly. Vasc. Health Risk Manag. 2015; 11: 251-263.

28. STAREE Study Investigators. A clinical trial of STAtin Therapy for Reducing Events in the elderly (STAREE). September 2015. Dostępne na: https://clinicaltrials.gov/ct2/show/NCT02099123. Data dostępu 11.04.2016. 